\title{
The action is where the social is! The ecosystem services concept and other ideas for enhancing stakeholder engagement in integrated mine closure planning
}

\author{
A Morrison-Saunders Edith Cowan University, Australia; North-West University, South Africa
}

\begin{abstract}
Effective stakeholder engagement is integral to effective integrated mine closure planning. All aspects of mine closure planning from the geotechnical to environmental, social and economic, need to be communicated to, and developed in conjunction with input from, the public and other stakeholders. This is why the action is where the social is! Using the latest International Council of Mining and Metals (ICMM) good practice guide for integrated mine closure as its basis, this paper addresses four topics: (1) the role of stakeholder engagement in mine closure planning; (2) best practice principles for stakeholder engagement derived mainly from environmental impact assessment processes; (3) using an ecosystem services approach to stakeholder engagement; and (4) stakeholder engagement in a digital world. Review of recent literature, recent research utilising ecosystem services assessment in planning for mine site rehabilitation and closure in Brazil and Australia, along with procedural examples from Western Australia, are used to explore the theory and practice of effective stakeholder engagement.

The ICMM guide establishes a role for mining companies in stakeholder engagement that extends beyond minimum legal compliance for consultation to enable deliberation, partnership, and a shared vision and responsibilities in mine closure planning and post-mining relinquishment. Where many components of mine closure planning are developed separately, including rehabilitation and closure criteria (which are often expressed using biophysical indicators), the integrated nature of ecosystem services thinking has been helpful when engaging with communities utilising pre- and post-mined areas to translate these into socially meaningful understanding of mine closure planning and its implementation. Mining company representatives involved in workshops conducted in Brazil and Australia indicated that the ecosystem services concept could be helpful in relation to mine closure planning, especially in relation to community engagement. Accelerating technological innovation and the use of digital media shows signs of promise for enhancing stakeholder engagement (for communities with good access to social media and the internet), although practice to date has emphasised consultation and basic communication with stakeholders rather than extending to full interaction and deliberation at the other end of the spectrum of public participation. Being a keynote address for the Mine Closure 2019 Conference, this paper is intended to have some relevance to all mine closure practitioners and to stimulate thinking and debate regarding ideas for enhancing stakeholder engagement in mine closure planning.
\end{abstract}

Keywords: stakeholder engagement, public participation, mine closure planning, ecosystem services assessment

\section{Introduction}

The Integrated Mine Closure: Good Practice Guide (Guide) published by the International Council of Mining and Metals (ICMM) (International Council of Mining and Metals [ICMM] 2019) provides the starting point for this paper, and specifically the role of stakeholder engagement in closure processes. My research interest as an academic has examined the translation of policies, legislation, and administrative practices into environmental and/or sustainability behaviours and outcomes. Building on a long-term emphasis on the effectiveness of environmental impact assessment (EIA) and its contribution to sustainable development, a 
recent focus has been on mine closure planning (Morrison-Saunders et al. 2016) and the concept of sustainable mining more generally (e.g. Bond \& Morrison-Saunders 2018).

My background is in environmental science and I have principally been located in university faculties having this broad subject focus. In taking the personal odyssey from a biophysical or natural environment interest to a sustainability one, my mantra in recent years - for example, when giving presentations to government, industry, community groups and students alike-is 'the action is where the social is!'. While I remain committed to promoting and upholding rigorous environmental science practices, I recognise that sustainability is an integrated concept requiring socio-economic considerations to also be appropriately taken into account. In terms of processes for doing this, stakeholder engagement and participation is fundamental in mine closure planning in order to realise effective sustainable development. To illustrate this point, Sustainable Development Goal 16.7 of the United Nations (United Nations 2015) is to 'Ensure responsive, inclusive, participatory and representative decision-making at all levels'. Similarly, ICMM (2019) notes that 'consistent and transparent engagement with stakeholders' and 'community participation in planning and implementing actions' are essential components of 'effective [mine] closure planning'. The importance of stakeholder engagement is emphasised throughout ICMM (2019), as well as other international guides to mine closure planning (Sánchez et al. 2014). It clearly has a role to play in many of the 'key elements of mine closure planning and implementation' (ICMM 2019), although how to go about doing this effectively is beyond the scope of the guide.

A key thesis of this paper is that the integrated nature of sustainability and of mine closure planning warrants the pursuit of techniques and approaches that take an integrated approach. By so doing, my expectation is that stakeholder engagement processes also themselves will ultimately be more effective.

The ecosystem services concept which came to international prominence in the Millennium Ecosystem Assessment (Millennium Ecosystem Assessment [MEA] 2005) is an integrated one that brings together environmental and social values. It has been employed extensively in recent years within EIA (Rosa \& Sánchez 2015; Slootweg 2015; Geneletti 2016; Hansen et al. 2018; Wawrzyczek et al. 2018) with Geneletti (2011) considering it as "instrumental to the development of integrated approaches to assess the sustainability of proposed plans". Rosa \& Sánchez (2016) note that one important potential contribution of ecosystem services to EIA practice is in "providing for more effective engagement of affected stakeholders". To date, however, discussion of this concept in the context of mine closure planning and in relation to stakeholder engagement in this context is comparatively scarce.

The purpose of this paper is to reflect on ways to enhance stakeholder engagement in integrated mine closure planning with a particular emphasis on the utility of taking an ecosystem services approach in this regard. Addressing this purpose invites reflection on recent initiatives in both mine closure planning and ecosystem services assessment viewed through the lens of stakeholder engagement. In so doing, other ideas for enhancing stakeholder engagement also surface and a secondary emphasis is upon these. The ideas discussed in this paper are intended to be of interest to all mine closure practitioners to some extent as there is ultimately no part of integrated mine closure planning without some element of public involvement, even if that only involves information disclosure and transparency.

\section{Approach and outline}

Being the basis for a keynote address at the Mine Closure 2019 Conference, my approach is to discuss contemporary ideas and issues regarding mine closure so as to provoke reflection, discussion, and debate by conference attendees or those utilising the proceedings after the event. While I draw on published material-and in that sense adopt an evidence-based argument up to a point-this paper is not itself intended to represent systematic or empirical research.

My focus is on literature from the fields of EIA, public participation, mine closure planning, and ecosystem services. This provides some inter-disciplinary basis for the paper, but is biased to the areas and specific works within these fields that I am most familiar with through my own academic research and teaching practice. I also highlight a recent research project that I have been involved in, principally as a supervisor of 
a PhD candidate responsible for carrying out the primary research effort. This research is of a case study and empirical nature, providing insights of how some of the theoretical concepts addressed in this paper can play out in practice.

The discussion that follows is divided into themes and topics commencing with broad concepts and then becomes more focused upon procedures and practices relevant to mine closure planning. I draw on examples from practice in Western Australia, being the jurisdiction in which I am mainly based, but also arguably one that is at the forefront of EIA and mining regulation worldwide. For example, the latest edition of the long-standing Introduction to Environmental Impact Assessment book (Glasson et al. 2019), which discusses best practices worldwide and showcases several examples of regulatory procedures and case studies from Western Australia. Regarding mining regulation, the most recent Fraser Institute survey of mining companies (Stedman \& Green 2018) positioned Western Australia as the second top jurisdiction in the world for mining investment, where the policy perception index utilised in this research includes aspects such as:

- Political stability.

- The certainty, stability, consistency, and timeliness of mining and environmental regulations.

- Avoidance of regulatory duplication or overlap.

- Legal processes that are fair, transparent, non-corrupt, timely, and efficiently administered.

- Clarity and certainty regarding environmental and heritage protection areas.

Implicit in the high scores awarded to Western Australia by Stedman \& Green (2018) is that the mining regulatory system is world class. More specific to mine closure, the ICMM (2019) feature several examples from Western Australia and of course it is the host jurisdiction for the Mine Closure 2019 Conference. My main purpose in utilising examples from Western Australia is to illustrate how broader theories and principles regarding ecosystem services and stakeholder engagement in mine closure planning can be put into practice.

\section{The action is where the social is: stakeholder engagement in mine closure planning}

Making the statement 'The action is where the social is' is not meant to imply that social considerations are the most important in mine closure planning. It is essential that geotechnical conditions at a minesite are known before any other consideration, whether financial, engineering, environmental, or social, in order to understand the best way to plan a mining operation including its eventual closure, rehabilitation, and transition to post-mining land uses (Fourie \& Brent 2005). Hence, ICMM (2019) lists safety, physical stability, and chemical stability as the first three in its list of closure principles, coming before socio-economic transition and ecological stability and the final three principles which relate to risk, cost-effectiveness, and long-term care. While an essential starting point, geotechnical and other scientific knowledge on its own does not serve much function and technical content needs to be communicated effectively with all stakeholders. These range across the full spectrum from other technical experts and regulators long-familiar with mining issues even if not scientific experts in mine closure, through to lay people with no prior knowledge, some of whom may be engaging in the process in a second language.

The centrality of public engagement to the mine closure process as a principle of regulatory best practice for mine rehabilitation recently was reiterated in an Australian Senate hearing by the Environment and Communications Reference Committee (2019). Similarly, ICMM (2019, p, 13) emphasises that "integrated mine closure should integrate stakeholder involvement and community consultation throughout the mining lifecycle". Beyond this broad exhortation, the ICMM Guide (ICMM 2019) subsequently identifies good practices for stakeholder consultation including the following five examples:

1. Closure vision, principles and objectives - developing closure objectives "in consultation with internal and external stakeholders"; "Involve stakeholders early in the development [of the company's closure vision] so that it can become a shared vision" that "will serve as an overarching 
guide for the decisions and their implications throughout the mining lifecycle", and that the "future landholders support for when the company has exited".

2. Post-closure land use - involving stakeholders when developing the post-closure land use plan including "meaningful incorporation of feedback" on the basis such a plan "will be far more likely to succeed" and to "Engage with regulators and other stakeholders including Indigenous Peoples, government agencies, community organisations and private landowners to obtain input on the potential land use options within the bounds of predicted land capability/suitability and company capacity".

3. Engagement for closure plan development - where good practice is to "Involve key affected stakeholders in the closure plan development, and keep broader external stakeholders informed and updated on progress". This should not be limited to the participation of elected leaders but "include informal and traditional representatives of women, youth, community associations, vulnerable groups and under-represented minorities".

4. Success criteria - "The setting of the success criteria should be done with inputs from multiple disciplines across the operation. Involvement and understanding of the targets by the local community and regulators should also be secured for ongoing alignment and agreement on the end point for mine closure". Further, there should be "documented agreement with the criteria".

5. Progressive closure - there should be "opportunities to involve external stakeholders with the design, implementation or monitoring of progressive closure works".

These aspects of mine closure planning involving stakeholders reveal the purpose or intended outcomes for mining companies to accomplish, but leave unexplained the best ways to go about doing this.

In the field of EIA, several specific tools have been developed for assessing social impacts and directly involving stakeholders in assessment processes, such as social impact assessment (Vanclay 2003; Esteves et al. 2012), health impact assessment (Harris-Roxas et al. 2012), gender impact assessment (United Nations Development Program 2013), poverty impact assessment (Asian Development Bank 2012), and human rights impact assessment (Kemp \& Vanclay 2013) which includes the concept of Free, Prior and Informed Consent of Indigenous Peoples (United Nations Human Rights Office of the High Commissioner 2013) as a primary tool for securing and protecting the rights of Indigenous people affected by mining and other development proposals (Hanna \& Vanclay 2013). These specific impact assessment tools resonate strongly with many of the Sustainable Development Goals established by the United Nations (2015) aimed at ensuring equity and justice for all is realised from development activity. I flag these here to further underscore my point that the action is where the social is but do not discuss them further in this paper. Instead I focus more specifically on stakeholder engagement by considering, in the next section, what best practice might entail in this regard, drawing on well-established thinking derived from EIA practices.

\section{Stakeholder engagement: best practice principles from environmental impact assessment}

There are numerous stakeholders involved in the lifecycle of development projects including new mining proposals which are subjected to EIA, some of which were evident in the previous extracts from ICMM (2019). Noble (2015) refers to there being multiple publics that need to be taken into consideration and engaged with during such decision-making processes, meaning that there will be different needs and expectations to accommodate.

Engaging stakeholders in EIA relates to the best practice principle of participative adopted by the International Association for Impact Assessment (IAIA) and the Institute of Environmental Assessment (IEA), UK (IAIA \& IEA 1999). Being participative means that an EIA process should provide opportunity for stakeholders to be informed and involved with their inputs and concerns being explicitly addressed in documentation and (approval) decision-making (André et al. 2006; Fundingsland Tetlow \& Hanusch 2012; 
IAIA \& IEA 1999). The broader principle of providing natural justice in decision-making - that people affected by a decision have a legal right to have input to the making of that decision (Bates 1997; Morrison-Saunders 2018; United Nations Economic Commission for Europe 1998)-is central to stakeholder engagement in EIA. It thus represents a legal obligation on EIA regulators to uphold certain minimum levels of public participation.

\subsection{Provisions for stakeholder engagement in Western Australia}

In Western Australia, the principle of natural justice is evident in the Environmental Protection Act 1986 (Government of Western Australia 1986), which provides for the ElA process in this jurisdiction. Section 40 of the Act empowers the Environmental Protection Authority (EPA) to "require any person to provide it with such information as is specified" ( $s 40(2) a)$, "require the proponent to undertake an environmental review and to report thereon to the Authority" (s20(2)b), to make any such report "to be made available for public review" (s40(4)b), to "determine the period ... and the manner in which public authorities or persons may make submissions" ( $(\mathrm{s} 4(4) \mathrm{b})$ and may "require the proponent to respond to any submissions made to the Authority in respect of that information or report in such manner as the Authority thinks fit" (s40(6)b). Thus, the formal provisions for stakeholder engagement relate to making documents available for public review and the receipt of written comments from interested parties. In the EIA administrative procedures (Government of Western Australia 2016), the EPA "encourages proponents... to consult with decision-making authorities and other relevant government agencies and stakeholders as early as possible" (s1.1). Similarly, in the accompanying EIA procedural guidance (Environmental Protection Authority 2018), the EPA makes it clear that the proponent is expected to "consult with relevant stakeholders" and that "evidence of effective stakeholder consultation" forms part of their assessment criteria for EIA proposals.

The Western Australian Mining Act 1978 (Government of Western Australia 1978) which importantly establishes a legal requirement for post-mining rehabilitation by providing that "any person carrying out mining operations on the land shall make good injury to the surface of the land or injury to anything on the surface thereof" (s 26(1)a) and contains even less detail regarding stakeholder engagement in the mine closure planning process. It simply defines a mine closure plan as a document in the form "required by the guidelines" (s 700(1)), which are publicly available (s 70P) and "approved by the Director General of Mines" (s 700(1)). The Mining Act 1978 further requires that a mining proposal "is in the form required by the guidelines" and contains "information of the kind required by the guidelines about proposed mining operations" (s 700(1)). The subsequent Guidelines for Preparing Mine Closure Plans, which were jointly prepared by the Department of Mines and Petroleum (DMP) (now the Department of Mines, Industry Regulation and Safety) and the EPA (DMP \& EPA 2015), makes it a requirement for the mining company to provide a "Stakeholder Engagement Register identifying the rehabilitation and closure consultation that has been conducted" along with a "Stakeholder Engagement Strategy identifying the stakeholder engagement to be undertaken prior to the submission of the next revision Mine Closure Plan" (DMP \& EPA 2015). The Western Australian guideline for preparing mine closure plans further outlines five principles of stakeholder engagement summarised as follows (DMP \& EPA 2015):

1. Principle 1: Identification of stakeholders and interested parties - these are defined as internal stakeholders, i.e. within the mining company responsible for mine planning, management, engineering, etc., and external stakeholders including government, non-government organisations (NGO), community members or groups and adjacent landowners.

2. Principle 2: Effective engagement is an inclusive process which encompasses all parties and should occur throughout the life of the mine - here it is noted that "a range of approaches to stakeholder engagement is able to be employed throughout the different stages or when certain issues need to be addressed" (p. 27). No details or suggestions on what approaches could or should be utilised are provided in the guideline, although reference is subsequently made to the spectrum of public participation (addressed in Section 4.3) of the International Association for Public Participation (IAP2) and an Australian government handbook on community engagement. 
3. Principle 3: A targeted communication strategy should reflect the needs of the stakeholder groups and interested parties - here the statement that it is "important that all stakeholders have their interests and concerns considered and where appropriate, addressed, and that the key stakeholders have an opportunity to provide feedback on the response or proposed action to address their interests and concerns, particularly when determining post-mining land use, closure objectives and outcomes", is in line with the legal provisions for stakeholder engagement outlined previously and a minimum compliance position being achieved.

4. Principle 4: Adequate resources should be allocated to ensure the effectiveness of the engagement process - this is self-explanatory and the supporting text is silent on details of what an effective stakeholder engagement process might entail.

5. Principle 5: Wherever practical, work with communities to manage the potential impacts of mine closure - here the DMP \& EPA (2015) "encourage regular engagement between a mining company and the local community(s) throughout all stages of mine development" and further note that "When managing potential environmental impacts from mine closure, an informed community (e.g. by establishing a consultative closure committee) can provide a useful forum for discussion and communication on closure issues". These directions again do not explicitly extend beyond a minimum compliance approach in regards the Western Australian legislation for EIA and mining.

These extracts from Western Australian legislation and procedural guidelines for mine closure planning align with the provisions for stakeholder engagement in ICMM (2019), as outlined previously. They hint at the need for mining companies to operate beyond compliance with the minimum legal requirements but do not extend so far as to illuminate what effective stakeholder engagement in that context might entail. This warrants consideration of the different types of stakeholders that may be encountered when planning for mine closure and the spectrum of public participation approaches.

\subsection{Stakeholder types}

A distinction can be made between stakeholders that are affected by a proposal and those simply with an interest in it (IAIA \& IEM 1999; Morrison-Saunders 2018). The IAP2 (2007) has established the following definitions in this regard:

- Stakeholders are "any individual, group of individuals, organisation or political entity with interest in the outcome of a decision" (p. 3). This includes those either "positively or negatively affected by a proposed intervention" (André et al. 2006).

- Public refers to those "stakeholders who are not typically part of the decision-making entity or entities" (IAP2 2007).

- Public participation means "any process that involves the public in problem-solving or decisionmaking and that uses public input to make better decisions" (IAP2 2007).

In contrast with these definitions, the mine closure guidance of Sánchez et al. (2014), DMP \& EPA (2015), and ICMM (2019) alike simply distinguishes between internal and external stakeholders, as outlined previously. Using the notion that environmental effects can be direct or indirect, or primary or secondary in nature (Noble 2015), the definitions above from IAP2 (2007) and IAIA \& IEM (1999) imply that greater participation opportunity should be extended to the directly affected parties, relative to others having only a broad interest or whom are indirectly affected. This notion accords with the reporting of United Nations Environmental Program (UNEP) (2018) that in some jurisdictions face-to-face meetings are only available to those directly affected by a proposal undergoing EIA. It accords with the range of approaches observed in ICMM (2019) in regards the engagement for closure plan development phase of mine closure planning identified in Section 3 previously. 


\subsection{The spectrum of public participation}

While participation in EIA is an international best practice principle (IAIA \& IEA 1999; Yang 2018), it is an area that attracts considerable criticism. For example, in recent times, there have been calls internationally for more meaningful, early, and ongoing public participation in EIA (Inter-American Development Bank 2017; World Bank 2017; UNEP 2018). Furthermore, in view of the spectrum of public participation possibilities (Arnstein 1969; IAP2 2014; Sheedy 2008) which extends from informing to consulting, involving, and ultimately through to empowering community participants, the extent to which the participative principle as outlined by IAIA \& IEM (1999) represents best practice is questionable. Sánchez et al. (2014) note that consultation in mine closure planning "assumes a dialogue between the parties" and that such processes should be interactive. Hartz-Karp et al. (2015) argue that, for a transition to sustainability to take place, it is necessary to move towards "deliberative collaborative governance" in which assessment processes explicitly incorporate "careful consideration of diverse public values, viewpoints and options in pursuit of a coherent public voice" which is implemented by means of "consensus-oriented decision-making" (i.e. affected persons actually help make the decision). A similar perspective is held by Sinclair et al. (2018) who see meaningful public participation being sought very early in the process and which incorporates the "insights of deliberative democracy, collaborative rationality and environmental justice" as hallmarks of what they refer to as next generation EIA practices. This means that best practice engagement of stakeholders would extend beyond simple participation. This position is implied in some of the ICMM (2019) guidance on stakeholder engagement noted previously, such as the development of a shared closure vision and obtaining community agreement on rehabilitation and closure success criteria.

It is important to realise that the practice of engaging stakeholders in EIA and other similar decision-making processes varies according to local political and cultural values, history, or traditions and institutions in place (Morgan 1998; Petts 1999; Noble 2015). Examples of such difference include:

- The tension between Western and non-Western views noted by Morgan (1998).

- The suggestion of O'Riordan \& Sewell (1981) that increasing levels of maturity in democracy leads to higher levels of public engagement in EIA practice.

- The observation of Bina et al. (2011) that public participation in impact assessment practice in China is limited because procedures are poorly defined, ignored or missing.

- The account of the Maldives provided by Niyaz \& Storey (2011) as a jurisdiction with little or no provision for public participation in EIA (they note a number of other jurisdictions where this is similarly the case). While in this case some proponents and their consultants do engage voluntarily with public stakeholders during EIA studies, this was found to be "ad hoc and outwardly superficial" (Niyaz \& Storey 2011), and the approach adopted in the Maldives judged to be not "fully fair or competent" by Zuhair \& Kurian (2016).

Thus, local socio-political context must be taken into consideration when deciding on what might constitute best practice stakeholder engagement. Importantly though, limitations in the regulatory regime regarding stakeholder engagement provisions should not exclude public participation. The short-fallings of regulation simply means that it falls upon proponents and their consultants to engage voluntarily with stakeholders during relevant decision-making processes (Morrison-Saunders 2018). As addressed in previous discussion, ICMM (2019) makes it clear that stakeholder engagement should occur throughout the mine closure planning process and that the onus is on mining companies to strive for and deliver on the best practices they extol. Ultimately, this means that mining companies will need to operate beyond legal compliance-at least with respect to the mine closure arrangements in place in Western Australia-in order to deliver effective stakeholder engagement and subsequent closure planning outcomes.

Further to the challenges posed by the multiple publics encountered during mine closure planning, along with potential shortcomings in regulation and guidance for how to engage stakeholders effectively are those associated with the complexity of mining projects and the breadth and depth of technical considerations. This is the challenge posed by the need for mine closure planning to be integrated. In the following section, 
some recent research conducted in Brazil and Western Australia demonstrating benefits of using an ecosystem services approach to mine closure planning to engage stakeholders is discussed.

\section{Using an ecosystem services approach to stakeholder engagement}

Ecosystem services are the benefits that society obtains from ecosystems (MEA 2005). Pioneering applications of ecosystem services assessment with mine closure planning have been recently undertaken in the doctoral research of Rosa et al. $(2018$ a, 2018b) in which I was involved in a partial supervisory capacity. The research involved application of an 'Ecosystem Service Assessment for Rehabilitation' framework (Rosa et al. 2018a) to bauxite mining operations being undertaken by the same company in Brazil and Western Australia. Previous investigations by the lead researchers into the use of ecosystem services assessment in EIA had found the concept to be useful in translating the importance of biodiversity to stakeholders and to provide an effective way to engage with communities (Rosa \& Sánchez 2016), because "it makes the link between ecosystems and human needs or benefits" (Rosa et al. 2018a). A brief account of key findings from this research regarding an ecosystem approach to stakeholder engagement in the context of mining rehabilitation and closure planning follows. Two main studies from the research program are summarised here: engagement with the communities in Brazil affected by bauxite mining and engagement with mining company representatives in Brazil and Australia. A separate paper addressing additional elements from the overall research program (Rosa et al. 2019) appears elsewhere in the Mine Closure 2019 Conference proceedings and is not duplicated here.

\subsection{Facilitating community engagement in mine closure planning using an ecosystem services approach}

In this study, semi-structured joint interviews were conducted with communities affected by the Juruti bauxite mine, which commenced operations in 2009, to understand for what purposes they use the pre-mined forest (in this region of the Amazon rainforest), and how they wish to use the rehabilitated forest post-mining. Interviews were conducted with 19 families within five communities in the vicinity of the mine site who have traditionally made use of the forest to extract a range of products including natural medicines, Brazil nuts and other bush foods, grasses and other fibres used for baskets and brooms, and timber used in house construction and to make boats which are the main source of transportation for these riverside communities. Discussion with community members was centred on the services provided by affected forest ecosystems when exploring what the pre-mined areas had been used for by the community and how they would like the company to return the land for post-mining use (Rosa et al. 2018b). The expectations, understanding, and perspectives of the communities were examined in the context of the regulatory provisions in place of mine closure planning, especially the rehabilitation goals and closure criteria.

Overall, it was found that the communities are not far from getting to an agreement with the mining company and regulators on post-mining land use. However, the broad rehabilitation goal currently approved by regulators focuses on biodiversity targets, does not explicitly capture a community perspective, and it is proving hard to deliver, notwithstanding that community members have also been employed by the mining company to work on progressive rehabilitation of the first pit area, which will have a 5,500 ha final footprint of mining. Taking the ecosystem services approach in stakeholder engagement was found to be useful in providing a common language to connect the company to communities. More specifically, it enabled a focused rehabilitation goal to be identified based on relevant services being provided to the community, which would deliver social and ecological benefits alike. As concluded in Rosa et al (2018b), an ecosystem services approach to stakeholder engagement "provides a pathway to identify desired post-mining land uses for communities, by selecting the relevant services for them". From that point-which should take place early in the closure planning cycle-it is intended that community perspectives can be directly included in decisionmaking for post-mining land use, promoting an agreement between them and the company, as advocated in ICMM (2019) Guide to integrated mine closure planning. 


\subsection{Mining company perspectives on the potential application of an ecosystem service approach to stakeholder engagement}

In the second study, workshops were conducted with company staff working with mine closure planning and rehabilitation at the Juruti mine site in Brazil, and in bauxite mining operations of the same company in the jarrah forests on the Darling Scarp of Western Australia which have been underway for the past 50 years (Rosa et al. 2018a). Each workshop commenced with a presentation about ecosystem services, including the outcomes of community engagement by the researchers with representatives of the Juruti communities outlined previously. Workshop participants were then asked to reflect on the utility of the ecosystem services approach to mine closure planning relative to current practices and the regulatory regime in operation at each mine site. Here I focus on the subsequent mining company perspectives relating specifically to stakeholder engagement aspects.

Overall, the ecosystem services approach was welcomed as a tool that "facilitates stakeholder engagement in defining post-closure planning objectives and targets" (Rosa et al. 2018a, p5). All mining company participants agreed that the approach is helpful in engaging communities to define post-mining land use and also to monitor the rehabilitation outcomes. In the Western Australian context, the ecosystem services concept was perceived to be a new label for already established practices as human uses of rehabilitated areas does form part of closure considerations, whereas in the Brazil context, it helped to reveal new social considerations for planning mine site rehabilitation. A particular benefit of taking this approach in Brazil was "to translate the current results into a language more comprehensible for communities, i.e. talking about environmental benefits to people instead of technical ecology issues such as the species diversity" (Rosa et al. 2018a). This included engagement to determine the rehabilitation recovery targets and closure criteria from a community perspective, i.e. talking about important benefits to them. An additional outcome welcomed by mining company representatives from the use of ecosystem services within community engagement was the concept of community-based monitoring because it could enhance the acceptance of rehabilitation efforts, again made feasible from the newly framed social basis for mine closure.

Mining staff in the Western Australian operation could see benefits in utilising an ecosystem services approach within mine closure planning to develop social impact assessment and to ensure social licence to operate. This is due to the enhanced community engagement opportunity that it provides and especially through "demonstrating that valued ecosystem services will be returned" (Rosa et al. 2018a) to affected communities. The integrated nature of the ecosystem services approach was also seen to be potentially useful in working towards closure criteria based upon integrated land use considerations, e.g. water supply and native food species for Indigenous peoples, plus associated forest and fire ecology management, rather than the current practice of individually itemised rehabilitation and closure criteria. It is noted that there are presently 30 completion criteria in use for these bauxite mining operations (Grant et al. 2007).

At the same time, mining staff observed that an ecosystem services approach does not resolve all challenges related to components involving stakeholder engagement in mine closure planning. As reported in Rosa et al (2018a), two inter-related challenges were identified:

1. How to accommodate opinions of different publics, such as of conservationists who simply want a self-sustaining forest ecosystem to be returned, versus recreationists seeking a forest landscape designed for human uses (including provision of new built infrastructure and other facilities).

2. That returning ecosystem services may deviate from the ecosystem reference currently established in the ecological restoration goal (i.e. meaning that mining results in net loss of biodiversity for other social purposes rather than restoring the affected ecosystem).

These challenges pertain to trade-off decision-making; a perennial challenge in any assessment process seeking to deliver sustainable development (Morrison-Saunders \& Pope 2013). Given that dialogue and clear communication will be necessary to resolve trade-offs, the benefits of taking an ecosystem services approach to stakeholder engagement outlined previously may nevertheless facilitate this process. 
Other potential means for enhancing stakeholder engagement that extends beyond the immediate practices of ecosystem services assessment and mine closure planning pertain to changes in communication technologies. Some ideas on stakeholder engagement in a digital world are the final topic for this paper (Section 6). Once again these are principally drawn from the field of EIA in the first instance.

\section{Stakeholder engagement in a digital world}

An appraisal of global megatrends by Retief et al. (2016), in the context of EIA practice, identified a range of potential challenges for practices associated with rapidly changing demographics, urbanisation, accelerating technological innovation and power shifts, along with resource scarcity and climate change. They noted, for example, that the "pace of technological innovation will continue to accelerate, especially in critical areas such as communication ... technology", while regarding power relations between citizens and their leaders highlighted the "rapidly increasing access to information and empowerment of individuals through digital media". Retief et al. (2016) ended their paper by positing four challenges for ElA practitioners arising from the global megatrends they examined. One of these-dealing with communication and participation -is the specific focus here.

Retief et al. (2016) point out that in the face of demographics, urbanisation, and technological innovation, assessment processes will "function in a context of increasingly rapid change". One particular challenge that they note relates to improvements in the "ability to generate and disseminate information" in the future, which presents opportunities to improve the efficiency of assessment processes, but also brings with it the "threat of potentially reducing effectiveness through incorporation of unmanageable information loads". This presents both opportunities and challenges for stakeholder engagement.

Retief et al. (2016) note that while best practice EIA "places a particular emphasis on the role and importance of information", and that the rapid pace of technological innovation in communication does provide "improved access to information through various information technology options", substantial "challenges relate to the management of information to ensure that it is sufficient, reliable, and usable to decision makers". In theory, social media should make it possible to simultaneously accomplish effective information provision, communication, and active participation in EIA practice. Several researchers have documented the rapid uptake of social media in EIA and other similar assessment processes around the world (Sinclair et al. 2017; Aaen et al. 2018), including the notion of e-consultation discussed by Althaus et al. (2018). Based on a review of practice in Hong Kong and Canada, Sinclair et al. (2017) reported that currently e-governance in EIA is "used predominantly for sharing information and not for generating dialogue" (p. 148), while a Danish study by Aaen et al. (2018) similarly reported that "the use of social media is predominantly limited to 'branding and provision of information' with an absence of 'participatory practices that have the purpose of sharing decision-making power or distributing power to the public".

An example of public engagement making use of digital technologies is the digital environmental impact statement trialled in the Netherlands (Glasson et al. 2019; Royal Haskoning DHV 2019). This employs an interactive digital platform that "provides information using videos, photos, maps, tables, infographics and even audio, moving away from the traditional text-based statements, yet retaining the fundamental integrity of the environmental impact statement" (Eijssen 2017). At the annual conference of IAIA in 2019 in Brisbane, Australia, I experienced a demonstration of virtual reality goggles provided by an oil and gas company to enable an 'experiential journey' through an environmental offset area associated with the company's operations in a remote area of Papua New Guinea. The special filming conducted for this demonstration enabled the user of the goggles to gain a 360-degree view of the environments being traversed as the film footage was taken. Permitting the user to swivel their head to control where they look when using the virtual reality goggles produces a visual equivalent of the surround sound experience now common in home-theatre set-ups. The claims of increasing interactivity, transparency, and accessibility relative to traditional document-based reporting proffered by Eijssen (2017) and Royal Haskoning DHV (2019) are apparent in these more interactive approaches utilising digital technologies; the degree to which it enhances dialogue and effective participation expected in best practice mine closure planning remains unclear. 
Sinclair et al. (2017) reported on cases where social media is starting to be used to engage community stakeholders in development campaigns and decision-making processes but the examples provided were instigated by the NGO sector in order to submit public petitions and lobby for change rather than being utilised by the proponents of development or EIA administrators. In Western Australia, Sutton et al. (2019) report on increasing use of social media platforms being made by the EPA in local EIA practice, conceding on the one hand that this engagement is primarily one-way communication but also noting that by monitoring other social media, such as third-party Facebook pages and blogs, and website campaigns, the EPA is able to respond to issues in a timely and effective manner. Aaen et al. (2018) found practices to be highly dependent on the developers' organisational culture, noting that 'the 'youngest' developer with the least consolidated practices seems most open to the possibilities of social media, whereas the developer most focused on legal issues is the least open to social media". They concluded that while social media offers considerable potential for engaging citizens who do not participate often in EIA processes and as a supplement to other public participation efforts currently in use, further exploration as to how the use of social media can be meaningfully adopted is still needed.

For effective EIA and mine closure planning practice, the challenge remains as to how technological innovation can be harnessed in public consultation and engagement processes. The examples reported on, to date, are predominantly with an EIA focus and have originated from densely populated regions in highly developed economies. Since much mining occurs in remote locations, e.g. in much of Western Australia, and in developing countries where reliable access to digital communications is not a given, this may temper the rate at which the transition to increasing use of digital technologies for stakeholder engagement in mine closure planning occurs. Nevertheless, it remains a contemporary and emerging opportunity for reflecting on ways to enhance stakeholder engagement practices.

\section{Conclusion}

This paper set out to provoke thought and reflection on the role of stakeholder engagement in integrated mine closure and ways to meet the best practice expectations laid out in the ICMM (2019). These extend beyond minimum legal compliance, with the onus on mining companies to voluntarily take on responsibility for effective stakeholder engagement that will deliver sustainable development during mine closure planning, rehabilitation, and eventual relinquishment. It warrants shifting practice away from information provision and basic consultation, towards the partnership, collaborating and empowerment side of the spectrum of public participation.

Taking an ecosystem services approach to stakeholder engagement was found to be useful in translating biophysical considerations into a socially meaningful understanding of mine closure planning and its implementation. This facilitated reaching agreement on post-mining land use in collaboration with mining company representatives and provided a useful vehicle for more effective stakeholder engagement.

Rapidly evolving digital technological innovation and the use of digital media is increasingly being used in contemporary public engagement practices in EIA and mine closure planning. While it shows signs of promise for enhancing stakeholder engagement where there is good access to these technologies, practice to date has emphasised consultation and basic communication with stakeholders, rather than extending to full interaction and deliberation at the other end of the spectrum of public participation.

The centrality of public engagement to the entire life mine closure planning lifecycle means that there is plenty of action with this socially-oriented aspect of closure planning which is of some relevance to all practitioners in the sector. It is hoped that this paper is helpful in stimulating thinking and debate around ways to enhance stakeholder engagement in future mine closure planning undertakings so as to deliver successful and sustainable post-mining outcomes.

\section{References}

Aaen, SB, Lyhne, I \& Nielsen, H 2018, 'The use of social media in impact assessment: experiences among national infrastructure developers in Denmark', Impact Assessment and Project Appraisal, vol. 36, no. 6, pp. 456-466. 
Althaus, C, Bridgman, P \& Davis, G 2018, The Australian Policy Handbook: A practical guide to the policy-making process, 6th edition, Allen \& Unwin, Sydney.

André, P, Enserink, B, Connor, D \& Croal, P 2006, Public Participation International Best Practice Principles, Special Publication Series No. 4, International Association for Impact Assessment, Fargo, viewed 17 December 2018, http://www.iaia.org/ uploads/pdf/SP4.pdf

Arnstein, SR 1969, 'A ladder of citizen participation', Journal of the American Planning Association, vol. 35, no. 4, pp. $216-224$.

Asian Development Bank 2012, Handbook on Poverty and Social Analysis A Working Document, viewed 25 May 2019 , https://www.adb.org/sites/default/files/institutional-document/33763/files/handbook-poverty-social-analysis.pdf

Bates, G (ed.) 1997, Butterworths Environmental Management and Law Dictionary, Butterworths Australia, Sydney, p. 137.

Bina, O, Jing, W, Brown, L \& Partidário, MR 2011, 'An inquiry into the concept of SEA effectiveness: Towards criteria for Chinese practice', Environmental Impact Assessment Review, vol. 31, pp. 572-581.

Bond, A \& Morrison-Saunders, A 2018, 'Environmental Impact Assessment and the quest for sustainable mining', in S Lodhia (ed.), Mining and Sustainable Development: Current Issues, Routledge Studies of the Extractive Industries and Sustainable Development, Routledge, London, pp. 47-64.

Department of Mines and Petroleum and Environmental Protection Authority 2015, Guidelines for preparing mine closure plans, Revision of the Guidelines for Preparing Mine Closure Plans, June 2011, viewed 12 April 2017, http://epa.wa.gov.au/sites/default/files/Policies_and_Guidance/DMP-EPA-Guidelines-Mine-Closure-Plans-080515.pdf

Environment and Communications Reference Committee 2019, Rehabilitation of mining and resources projects and power station ash dams as it relates to Commonwealth responsibilities, Senate Printing Unit, Canberra, viewed 21 March 2019, https://www.aph.gov.au/ /media/Committees/ec_ctte/MiningandResources/Report/report.pdf?la=en

Environmental Protection Authority 2018, Environmental Impact Assessment (Part IV Divisions 1 And 2) Procedures Manual, Western Australia, viewed 27 March 2019, http://epa.wa.gov.au/sites/default/files/Policies_and_Guidance/EIA Procedures Manual 300418.pdf

Eijssen, P 2017, 'Going digital', The Environmentalist, pp. 2-3, viewed 30 March 2019 https://www.royalhaskoningdhv.com//media/royalhaskoningdhvcorporate/

Esteves, AM, Franks, D \& Vanclay, F 2012, 'Social impact assessment: the state of the art', Impact Assessment and Project Appraisal, vol. 30, no. 1, pp. 34-42.

Fourie, A \& Brent, AC 2005, 'A project-based Mine Closure Model (MCM) for sustainable asset Life Cycle Management', Journal of Cleaner Production, vol. 14, no. 12-13, pp. 1085-1095.

Fundingsland Tetlow, M \& Hanusch, M 2012, 'Strategic environmental assessment: the state of the art', Impact Assessment and Project Appraisal, vol. 30, no.1, pp. 15-24.

Geneletti, D 2011, 'Reasons and options for integrating ecosystem services in strategic environmental assessment of spatial planning', International Journal of Biodiversity Science, Ecosystem Services \& Management, vol. 7, no. 3, pp. 143-149.

Geneletti, D 2016, Handbook on Biodiversity and ecosystem services in impact assessment, Edward Elgar Publishing, Cheltenham.

Glasson, J, Therivel, R \& Chadwick, A 2019, Introduction to Environmental Impact Assessment, $5^{\text {th }}$ Edition, Routledge, Oxon.

Government of Western Australia 1978, Mining Act 1978, Australia, viewed 24 May 2019 https://www.legislation.wa.gov.au/ legislation/statutes.nsf/law_a517.html

Government of Western Australia, Environmental Protection Act 1986, Australia, viewed 24 May 2019 https://www.legislation.wa. gov.au/legislation/statutes.nsf/law_a252_currencies.html

Government of Western Australia 2016, 'Environmental Impact Assessment (Part IV Divisions 1 And 2) Administrative Procedures 2016', Environmental Protection Act 2016, Western Australian Government Gazette No. 223, pp. 5601-5616, viewed 27 March 2019, http://epa.wa.gov.au/sites/default/files/Policies_and_Guidance/Gg223.pdf

Grant, CD, Ward, SC \& Morley, SC 2007, 'Return of ecosystem function to restored bauxite mines in Western Australia', Ecology Restoration, vol. 15, no. 4, pp. S94-S103.

Hanna, P \& Vanclay, F 2013, 'Human rights, Indigenous peoples and the concept of Free, Prior and Informed Consent', Impact Assessment and Project Appraisal, vol. 31, no. 2, pp. 146-157.

Hansen, K, Malmaeus, M, Hasselström, L, Lindblom, E, Norén, K, Olshammar, M, ... \& Soutukorva, A 2018, 'Integrating ecosystem services in Swedish environmental assessments: an empirical analysis', Impact Assessment and Project Appraisal, vol. 36, no. 3, pp. 253-264.

Harris-Roxas, B, Viliani, F, Bond, A, Cave, B, Divall, M, Furu, P, ... \& Winkler, M 2012, 'Health impact assessment: the state of the art', Impact Assessment and Project Appraisal, vol. 30, no. 1, pp. 43-52.

Hartz-Karp, J, Pope, J \& Petrova, P 2015 'A Deliberative Collaborative Governance Approach to Sustainability Assessment', in A Morrison-Saunders, J Pope \& A Bond (eds), Handbook of Sustainability Assessment, Research Handbooks on Impact Assessment, Edward Elgar, Cheltenham, pp. 375-402.

International Association for Impact Assessment \& Institute for Environmental Assessment UK 1999, Principles of Environmental Impact Assessment Best Practice, viewed 17 Feb 2018, http://www.iaia.org/uploads/pdf/principlesEA 1.pdf

International Association for Public Participation 2007, Foundations of Public Participation, viewed 11 July 2017, http://static.qwad.com.au/iap2/files/09FoundationsBrochure_PrintReady.pdf

International Association for Public Participation 2014, IAP2's Spectrum of Public Participation, viewed 17 Feb 2019 , https://www.iap2.org.au/Tenant/C0000004/00000001/files/IAP2_Public_Participation_Spectrum.pdf

International Council on Mining \& Metals 2019, Integrated Mine Closure Good Practice Guide, 2nd edn, viewed 27 March 2019 , http://www.icmm.com/website/publications/pdfs/closure/190107_good_practice_guide_web.pdf 
Inter-American Development Bank 2017, Meaningful Stakeholder Consultation, IDB Series on Environmental and Social Risk and Responsibility, viewed 30 March 2019, https://publications.iadb.org/bitstream/handle/11319/8454/MeaningfulStakeholder-Consultation.pdf?sequence $=3$

Kemp, D \& Vanclay, F 2013, 'Human rights and impact assessment: clarifying the connections in practice', Impact Assessment and Project Appraisal, vol. 31, no. 2, pp. 86-96.

Millennium Ecosystem Assessment 2005, Ecosystems and Human Well-being: Synthesis, Island Press, Washington, DC, viewed 23 May 2019, https://www.millenniumassessment.org/documents/document.356.aspx.pdf

Morgan, RK 1998, Environmental Impact Assessment: A Methodological Perspective, Kluwer Academic, Dordrecht.

Morrison-Saunders, A 2018, Advanced Introduction to Environmental Impact Assessment, Edward Elgar, Cheltenham.

Morrison-Saunders, A, McHenry, MP, Rita Sequeira, A, Gorey, P, Mtegha, H \& Doepel, D 2016, 'Integrating mine closure planning with environmental impact assessment: Challenges and opportunities drawn from African and Australian practice', Impact Assessment and Project Appraisal, vol. 34, no. 2, pp. 117-128.

Morrison-Saunders, A \& Pope, J 2013, 'Conceptualising and managing trade-offs in sustainability assessment', Environmental Impact Assessment Review, vol. 38, pp. 54-63.

Niyaz, A \& Storey, D 2011, 'Environmental management in the absence of participation: a case study of the Maldives', Impact Assessment and Project Appraisal, vol. 29, no. 1, pp. 69-77.

Noble, B 2015, Introduction to Environmental Impact Assessment: A Guide to Principles and Practice, $3^{\text {rd }}$ edn, Don Mills, Oxford University Press, Ontario.

O'Riordan, T \& Sewell, WRD 1981, 'From project appraisal to policy review', in T O’Riordan \& WRD Sewell (eds), Project Appraisal and Policy Review, John Wiley \& Sons, New York, pp. 1-28.

Petts, J 1999, 'Public participation and environmental impact assessment', in J Petts (ed.), Handbook of Environmental Impact Assessment Volume 1: Environmental Impact Assessment: Process, Methods and Potential, Blackwell Science, Oxford, pp. 145-177.

Retief, F, Bond, A, Pope, J, Morrison-Saunders, A \& King, N 2016, 'Global megatrends and their implications for environmental assessment practice', Environmental Impact Assessment Review, vol. 61, pp. 52-60.

Rosa, JCS, Morrison-Saunders, A, Sánchez, LE, Hughes, M \& Geneletti, D 2019, 'Applying ecosystem services assessment in closure planning to enhance post-mining land use outcomes: learning from bauxite mining in Brazil and Australia', in AB Fourie \& M Tibbett (eds), Proceedings of the 13th International Conference on Mine Closure, Australian Centre for Geomechanics, Perth, pp. 937-950.

Rosa, JCS \& Sánchez, LE 2015, 'Is the ecosystem service concept improving impact assessment? Evidence from recent international practice', Environmental Impact Assessment Review, vol. 50, pp. 134-142.

Rosa, JCS \& Sánchez, LE 2016, 'Advances and challenges of incorporating ecosystem services into impact assessment', Journal of Environmental Management, vol. 180, pp. 485-492.

Rosa, J, Morrison-Saunders, A \& Sánchez, L 2018a, 'Improving Stakeholder Engagement in Closure Planning through an Ecosystem Services Approach', Proceedings for Planning for Closure 2018, Gecamin, Santiago, https://www.gecaminpublications.com /planningforclosure2018/

Rosa, J, Sánchez, L \& Morrison-Saunders, A 2018b, 'Getting to "agreed" post-mining land use - An ecosystem approach', Impact Assessment and Project Appraisal, vol. 36, no. 3, pp. 220-229.

Royal Haskoning DHV 2019, The New Environmental Impact Statement, viewed 30 March 2019, https://www.royalhaskoningdhv.com/en-gb/specials/digital-eis

Sánchez, LE, Silva-Sánchez, SS \& Neri, AC 2014, Guide for Mine Closure Planning, Instituto Brasileiro de Mineração, Brazil, viewed 30 March 2019, http://www.ibram.org.br/sites/1300/1382/00004552.pdf

Sheedy, A 2008, Handbook on Citizen Engagement: Beyond Consultation, Canadian Policy Research Networks, viewed 17 Feb 2018 , https://ccednet-rcdec.ca/sites/ccednet-rcdec.ca/files/handbook_on_citizen_engagement.pdf

Sinclair, AJ, Doelle, M \& Gibson, RB 2018, 'Implementing next generation assessment: A case example of a global challenge', Environmental Impact Assessment Review, vol. 72, pp. 166-176.

Sinclair, AJ, Peirson-Smith, T \& Boerchers, M 2017, 'Environmental assessments in the Internet age: the role of e-governance and social media in creating platforms for meaningful participation', Impact Assessment and Project Appraisal, vol. 35, no. 2, pp. 148-157.

Slootweg, R 2015, 'Ecosystem services in strategic environmental assessment: are we missing the point of a simple concept?', Impact Assessment and Project Appraisal, vol. 34, no. 1, pp. 79-86.

Stedman, A \& Green, KP 2018, Fraser Institute Annual Survey of Mining Companies 2018, Fraser Institute, viewed 27 March 2019 , https://www.fraserinstitute.org/sites/default/files/annual-survey-of-mining-companies-2018.pdf

Sutton, A, Weston, D \& Morrison-Saunders, A 2019, Being agile: evolving IA in a changing world, 39th Annual Conference of the International Association for Impact Assessment, Brisbane.

United Nations 2015, Transforming our World: The 2030 Agenda for Sustainable Development, A/RES/70/1, viewed 17 October 2017, https://sustainabledevelopment.un.org/content/documents/21252030 Agenda for Sustainable Development web.pdf

United Nations Development Program 2013, Integrating HIV and Gender-Related Issues into Environmental Assessment in Eastern and Southern Africa, viewed 24 May 2019, https://www.undp.org/content/dam/undp/library/hivaids/ English/Guidelines_for_Integrating_HIV_and_Gender_related_Issues_into_Environmental_Assessment_in_Eastern_and_So uthern_Africa.pdf 
United Nations Economic Commission for Europe 1998, Aarhus Convention on Access to Information, Public Participation and Access to Justice in Environmental Matters, viewed 21 February 2019, https://www.unece.org/fileadmin/DAM/env/pp/ documents/cep43e.pdf

United Nations Environment Program 2018, Assessing Environmental Impacts - A Global Review of Legislation, Nairobi, viewed 9 Feb 2019, http://wedocs.unep.org/handle/20.500.11822/22691

United Nations Human Rights Office of the High Commissioner 2013, Free, Prior and Informed Consent of Indigenous Peoples, Geneva, viewed 25 May 2019, https://www.ohchr.org/Documents/Issues/IPeoples/FreePriorandlnformedConsent.pdf

Vanclay, F 2003, 'International principles for social impact assessment', Impact Assessment and Project Appraisal, vol. 21, no. 1, pp. 5-12.

Wawrzyczek, J, Lindsay, R, Metzger, MJ \& Quétier, F 2018, 'The ecosystem approach in ecological impact assessment: Lessons learned from windfarm developments on peatlands in Scotland', Environmental Impact Assessment Review, vol. 72, pp. 157-165.

World Bank 2017, The World Bank Environmental and Social Framework, International Bank for Reconstruction and Development, viewed 30 March 2019, http://pubdocs.worldbank.org/en/837721522762050108/Environmental-and-Social-Framework.pdf

Yang, T 2018, 'The Emergence of the Environmental Impact Assessment Duty as a Global Legal Norm and General Principle of Law', Hastings Law Journal, viewed 30 March 2019, https://papers.ssrn.com/sol3/papers.cfm?abstract_id=3202454

Zuhair, MH \& Kurian, PA 2016, 'Socioeconomic and political barriers to public participation in EIA: implications for sustainable development in the Maldives', Impact Assessment and Project Appraisal, vol. 34, no. 2, pp. 129-142. 